\title{
The Effect of Kinesio Taping on Muscle Strength Improvement, Blood Fatigue Factors, Muscle Fatigue and Damage Index
}

\author{
Min-Sun Lee, II-Young Paik ${ }^{1}$, Yi-Sub Kwak ${ }^{2}$, Hee-Tae No ${ }^{1}$ and Hwa-Eun Jin ${ }^{1 *}$ \\ Department of Physical Theraphy, Sun Moon University, 100 Kalsan-ri Tangjeong-myeon, Asan-si Chungnam, Korea \\ ${ }^{1}$ Department of Physical Education, Yonsei University, 262 Seongsanno, Seodaemnn Gu, Seoul, Korea \\ ${ }^{2}$ Department of Physical Education, Dong-Eui University, 995 Eomgwangno, Busanjin-gu, Busan, Korea
}

Received January 28, 2010 / Accepted March 16, 2010

\begin{abstract}
The purpose of this study was to examine the effect of kinesio taping on muscle strength and changes of muscle fatigue and damage. 10 male subjects participated in 1-RM and isometric cybex muscle strength tests with and without taping application. Muscle strength (bench press, leg press) and extension (knee, shoulder) strength were significantly increased after taping, but there was no significant difference in flexion (knee, shoulder) strength. The concentration of fatigue factors (ammonia, phosphorous), muscle damage index substances (CK, LDH), IGF-I and creatinine were reduced after taping, but there were no significant differences.
\end{abstract}

Key words : Kinesio taping, fatigue, muscle damage, creatinine, IGF-I

\section{서 론}

최근 스포츠는 날로 눈부시게 발전하고 있다. 많은 스포츠 종목에서 다양한 전술의 구사, 월등한 체력의 향상, 난이도 높은 기술의 표현 등 여러 분야에서 괄목할 만한 발전을 이루 어 온 것은 사실이다. 그러나 이러한 급속한 발전과 더불어 다양한 스포츠 부상이 따르는 것은 피할 수 없는 사실이고, 최고 위치에 있는 선수나 높은 기술을 구가하는 일류 스포츠 선수일수록 매일같이 더 많은 부상의 위험 속에서 연습과 경 기를 하고 있다고 볼 수 있다.

근래 몇 년 전부터 TV나 신문 등 대중전달 매체를 통하여 프로선수 뿐만 아니라 아마추어 선수들이 무릎이나 상완 관절 부위에 테이핑을 하고 나와 경기를 하는 것을 종종 볼 수 있는 데, 이것은 부상의 예비 방지로서 기존에 사용되어 왔던 sports taping과는 별도로 kinesio taping을 많이 사용하는 것을 볼 수 있다. Kinesio taping은 특정부위에 탄력을 가진 테이프를 특정 부위에 붙이는 방법으로 1985년 일본인 의사 Arikawa에 의해 개발된 이후 비교적 간편하게 손쉽게 배울 수 있다는 장점 때문에 스포츠 분야 및 일상생활에서도 다양하게 이용되 고 있다.

운동선수의 근력, 근지구력, 근 파워 등의 근 기능은 경기력 향상과 밀접한 관련이 있다. 최근 근 기능 향상을 위한 다양한 방법들이 개발되어 이용되고 있는데 그 중에서 테이핑요법은 손쉽게 배울 수 있고 현장 적용이 쉽기 때문에 일선 스포츠 현장에서 자주 활용되고 있다.

\footnotetext{
${ }^{*}$ Corresponding author

Tel : +82-2-2123-3199, Fax : +82-2-2123-3199

E-mail : jhwaeun@hotmail.com
}

테이핑요법은 피부에 흐르는 전기적인 흐름을 조절하여, 피 부를 통해 바로 밑의 근육이나 내장기에 전자기적인 자극을 줌으로서 관절의 보강 및 보호, 부종 감소, 또는 급성 손상 시 관리를 위해 고정을 목적으로 적용해 왔으며[22], 최근에는 약물치료 없이 근골격계의 손상시 피부 및 근육에 직접 테이프 를 부착하여 통증의 감소를 꾀할 뿐 아니라[33], 전문적인 운동 선수에게는 운동기능 향상과 스포츠 상해 예방의 차원으로 활 용되고 있다[29]. 또한, 근력, 근지구력 등의 기능 향상을 목적으 로도 테이핑 방법들이 개발되어 다양하게 적용하고 있다[34].

특히, 기능성 테이프로 일컬어지고 있는 kinesio taping은 관절을 움직이는 근육의 결에 따라 붙여줌으로써 근육과 피부 사이의 혈액과 림프순환을 증가시켜 근육의 운동기능을 향상 시키기 때문에 스포츠 현장에서 상해를 예방하고 손상된 근육 및 관절의 기능을 개선시켜 2차 손상을 예방[32]시켜 준다. 또 한 약한 근육을 지지함으로써 근기능을 교정하고, 혈액과 림 프액 흐름을 증진시킴으로 울혈(congestion)을 감소시키며, 신 경계를 자극함으로써 통증을 감소시킨다[14,27]. 그리고, 근경 련을 예방함으로써 조절 불가능한 관절을 개선할 수 있으며, 자세의 안전성 유지 및 체력을 증가시켜 주고 $[9,41]$ 근력, 근 지구력, 및 근 파워 등의 근 기능을 개선시켜 경기력 향상에 도움을 주고 있다[16].

테이핑의 적용은 근골격계 질환 및 내과적 질환의 치료에도 활용되고 있는데 특히 골관절염[1], 무릎통증[31] 및 골절[2] 환자들에서 통증완화 및 재 골절 위험의 감소 효과가 보고되 고 있다. 이것은 테이핑의 주기능인 휴지모터 운동반사에 의 한 끊임없는 근 수축으로 인하여 근육의 긴장도를 조절하고 근방추와 골지 건기관의 자극을 통하여 근 긴장의 완화를 이 끌어 내며 상호억제 효과를 이용한 근육의 강화와 회복 그리 
고 혈액, 림프 및 조직액의 순환을 촉진[11]시켜 관절의 기능이 향상되었기 때문이다.

체력요소들과 관련된 연구들을 살펴보면, Wee 등[40]은 대 퇴부에 kinesio taping을 적용하였을 때 등속성 운동시 슬관절 의 근력 및 근 파워에 유의한 영향을 미친다고 하였으며, Garrack [9]은 족관절 테이핑이 서전트 점프, $100 \mathrm{~m}$ 달리기, 멀리뛰기 등 근력을 동원하는 체력 요소에 효과적이라 보고하 였다. No [30]도 kinesio taping을 적용한 결과 근력 증가와 운동능력 지속효과를 가져와 골프에서 비거리 향상을 가져왔 다고 보고하였다. 즉 이것은 kinesio taping 적용이 체력, 근력 및, 근 파워 등의 향상과 밀접한 관련이 있음을 의미하는 결과 이다. 이외에도 많은 연구들 $[4,15,18]$ 이 테이핑의 효과에 대해 발표하였으나, 대부분의 연구들은 테이핑 적용 당시에 나타나 는 근 기능의 발현여부를 알아보는 것이었다.

이미 여러 선행연구에서는 일반인과 환자들을 대상으로 kinesio taping의 부상방지 및 경기력 향상 효과에 대하여 입증 하였으며, 다양한 분야에서 응용하여 적용되고 있다. 하지만 이들 연구의 단점은 특정 근육 또는 주동근에만 부분적으로 테이핑 요법을 적용하거나, 특정 동작에 있어서의 근력 향상 을 중점적으로 관찰한 연구가 대부분이어서 전신에 대한 테이 핑 요법이 각 근육 부위에 어떠한 영향을 미치는지에 관한 통합적인 관찰은 미흡하였다. 또한 주로 1-RM 또는 등속성 운동능력 등의 물리적인 수치를 통하여 근력의 변화를 확인하 거나, 특정 근육에 대한 반복적인 동작 이후의 변화를 혈중으 로 관찰하는 등의 제한적인 연구들이 대부분이었다.

그리고, 인체의 체액 중 혈액은 전신을 순환하는 동안에 산 소 $\left(\mathrm{O}_{2}\right)$, 이산화탄소 $\left(\mathrm{CO}_{2}\right)$ 운반을 비롯해서 각종 영양물질, 호 르몬 등의 대사물질을 운반할 뿐만 아니라 그 외에도 생체방 어 작용, 조직액(tissue fluid), 이온(ion), 삼투압, 체온 등을 조 절하는 기능을 가지고 있다. 그러므로 운동 후 혈액검사를 통 한 생리 및 생화학적인 변화를 분석하는 것은 기전에 대한 이해뿐만 아니라 운동을 수행할 수 있는 능력과 운동 수행의 효과 및 그로인한 근 손상 및 피로를 판단할 수 있는 중요한 지표가 된다. 그러나 현재까지 진행된 kinesio taping과 관련 한 대부분의 연구들은 단지 국부적인 근육에서 기계적인 요소 들만을 조사하였다.

따라서 본 연구에서는 정기적인 신체활동에 참여하는 건강 한 대학생 10명을 대상으로 kinesio taping을 적용한 후 근력 과 혈중 피로지표 물질 및 근 손상 지표물질의 농도변화를 비교 분석하여 kinesio taping이 근력 향상에 미치는 영향을 생리학적으로 규명하고자 하였다.

\section{재료 및 방법}

\section{연구 대상}

본 연구는 남자 대학생 10 명을 대상으로 하였으며, 연구 대
상자의 신체적 특성은 Table 1에 나타나 있다.

\section{최대근력(1-RM) 테스트}

Taping 적용 전과 후 모두, Central Fitness社의 Machine을 이용하여 상체(Bench Press)와 하체(Leg Press) 최대 근력을 측정하였다. 모든 피험자는 사전 test 전 종목에 따른 올바른 자세를 숙지하도록 하여 부위별 기본 스트레칭 동작을 지침에 따라 3회 씩 반복하였다. 그 후, 각 동작 시 최초의 낮은 부하에 서 점진적으로 부하를 증가시켰으며 최대의 힘으로 1 회 수행 한 후 더 이상 반복할 수 없는 무게를 1-RM으로 기록하였다.

\section{등속성 근력 테스트(Cybex Test)}

Taping 적용 전과 후 모두, 등속성 근력 측정 장치(Cybex社 (美), Cybex 6000 Isokinetic Dynamometer)를 이용하여 각속 도 $60^{\circ} / \mathrm{sec}$ 에서 어깨 관절(shoulder)의 굴근/신근(Flexors/ Extensors)과 슬관절(Knee joint)의 굴근/신근(Flexors/ Extensors)을 측정하였다. 4 회 반복 수행 결과 가장 높은 Torque를 나타낸 값을 Peak Torque로 결정하였으며 체중으 로 나눈 값 $(\mathrm{Nm} / \mathrm{kg}(\%))$ 을 본 실험에서의 data로 사용하였다.

\section{Kinesio taping 방법}

Kinesio taping은 승모근, 삼각근, 극상근, 상완이두근, 상완 삼두근, 대흥근, 복직근, 대퇴 사두근, Hamstring muscle, 비복 근, 전경골근 총 11 부위에 부착하였다.

\section{근손상 유도 방법}

Taping 적용 전과 후 모두, 근 손상을 유도하기 위해 1-RM $85 \%$ 의 강도로 각 종목(Bench Press, Lat Pull Down, Arm Curl, Shoulder Press, Leg Press, Leg Extension, Leg Curl)에 따른 운동을 실시하였다. Taping 적용 전, 각 Set간 휴식은 2분 30 초로 제한하고 반복은 최대로 실시하였으며, 반복수는 각 종목 및 set별로 기록하여 taping 적용 후에도 동일하게 실시 하였다.

\section{혈액채취 및 분석 방법}

혈액 채취는 두 가지 실험조건(taping 전, 후)에서 암모니아, 무기인산, IGF-I, creatinine 분석을 위해 3회, $\mathrm{CK}, \mathrm{LDH}$ 분석을 위해 6회를 실시하였으며, 채취된 혈액은 채취 후 즉시 원심 분리 하였다. Ammonia, LDH, IGF-I 분석을 위해 Spectrophotometer (Roche Diagnostics社(스위스), Cobas Integra 800)를 이용하 였으며, phosphorous와 CK는 자동생화학 분석기(Hitachi社

Table 1. Physique characteristics of subjects

\begin{tabular}{ccccc}
\hline $\mathrm{N}$ & Age $(\mathrm{yr})$ & Height $(\mathrm{cm})$ & Weight $(\mathrm{kg})$ & Body fat $(\%)$ \\
\hline 10 & $21.5 \pm 2.2$ & $173.23 \pm 3.34$ & $75.04 \pm 11.46$ & $15.71 \pm 5.18$ \\
\hline
\end{tabular}

Values are mean \pm standard deviation. 
(日), Hitachi 7150)를 이용하였다. 그리고 creatinine 분석은 자동생화학 분석기(Hitachi社(日), TBA-200FR)를 이용하였다.

\section{자료처리}

본 실험의 결과는 SPSS 통계 package (v. 11.0)를 이용하여, 기술통계량을 산출하였다. 혈중 피로 지표물질(ammonia, phosphorous)과, 근 손상 지표물질(CK, $\mathrm{LDH})$, creatinine, IGF-I의 변화형태 비교는 taping 처치 조건과 시기를 반복 측 정하는 이원 분산분석법(two-way ANOVA)을 이용하여 분석 하였고, 유의수준은 0.05 로 설정하였다.

\section{결 과}

\section{체중 및 체지방 변화}

Taping 적용 전후의 체중 및 체지방은 거의 차이가 없었으 며 이를 통하여 처치 전후의 동질성을 확인할 수 있었다.

\section{1-RM 변화}

Taping 적용 전후의 1-RM 변화는 Table 2에 나타나 있으며, Bench Press의 경우, 사전에 비해 사후에 $7 \mathrm{~kg}$ 증가하였고, Leg press는 사전에 비해 사후에 $22.60 \mathrm{~kg}$ 의 증가를 보였다. 처치 전후에 따른 통계적 유의성을 검증하기 위하여 paired sample t-test를 실시한 결과 Bench press와 Leg press 모두 통계적으로 유의하였다 $(\mathrm{p}<0.001)$.

\section{등속성 운동능력}

Taping 적용 전후의 1-RM 변화는 Table 3에 나타나 있다. 등속성 운동능력 중 근력의 향상도를 분석하기 위하여 $60^{\circ}$ /sec의 각속도에서 슬관절(knee)과 어깨관절(shoulder)의 내·외전 시 체중당 최대회전력(Peak torque $\% \mathrm{BW}$ )을 관찰하 였다. 등속성 운동능력은 슬관절 및 견관절에서 extension과 flexion 모두 사후에 높았으며 그 차이는 슬관절에서 더 크게

Table 2. Comparison of 1-RM

\begin{tabular}{ccc}
\hline Group & Bench Press $(\mathrm{kg})$ & Leg Press $(\mathrm{kg})$ \\
\hline $\mathrm{NK}$ & $70.50 \pm 14.80$ & $226.90 \pm 19.20$ \\
$\mathrm{~K}$ & $77.50 \pm 16.87$ & $249.50 \pm 16.06$ \\
\hline
\end{tabular}

Values are mean \pm standard deviation.

K: with kinesio taping, NK: without kinesio taping.

Table 3. Comparison of cybex

\begin{tabular}{cccccc}
\hline \multirow{2}{*}{ Group } & \multicolumn{2}{c}{ Knee Joint } & & \multicolumn{2}{c}{ Shoulder Joint } \\
\cline { 2 - 3 } \cline { 5 - 6 } & Extension & Flexion & & Extension & Flexion \\
\hline NK & $251.30 \pm 49.95$ & $150.10 \pm 32.30$ & & $117.20 \pm 24.33$ & $84.40 \pm 11.31$ \\
K & $276.50 \pm 53.72$ & $160.90 \pm 35.03$ & & $123.40 \pm 22.71$ & $87.90 \pm 10.77$ \\
\hline
\end{tabular}

Values are mean \pm standard deviation.

K: with kinesio taping, NK: without kinesio taping.
나타났다.

우선 슬관절의 경우 extension은 사전에 비해 사후에 25.20 $\mathrm{Nm} / \mathrm{kg}(\%)$, flexion은 사전에 비해 사후에 $10.80 \mathrm{Nm} / \mathrm{kg}(\%)$ 가 증가하였으며, 통계분석 결과 extension $(\mathrm{p}<0.001)$ 에서는 유의한 차이를 보였으나 flexion에서의 차이는 유의하지 못하 였다.

어깨관절의 변화를 살펴보면, extension의 경우 사전에 비 해 사후에 $6.20 \mathrm{Nm} / \mathrm{kg}(\%)$ 의 통계적으로 유의한 증가를 보였 지만(p<0.05), flexion에서는 사전보다 사후 $3.50 \mathrm{Nm} / \mathrm{kg}(\%)$ 의 증가를 보였으나 통계적으로 유의한 차이는 나타나지 않았다.

\section{혈중 피로 지표물질의 변화}

혈중 피로지표 물질인 ammonia와 phosphorous 농도는 운 동 직후 가장 높은 수치를 보이다 회복 30 분 시기에서 안정시 만큼 회복되었다. Taping 처치 전후에 대한 혈중 ammonia 및 phosphorous의 평균 농도는 사전보다 사후 더 낮은 수치를 보였으나 테이핑 처치 전후 및 채혈시점 간의 ammonia 농도 에 대한 ANOVA 결과에서 채혈시기 간에서는 통계적으로 유 의한 차이 $(\mathrm{p}<0.001)$ 가 나타났으나 taping 전후에 따른 차이는 유의하지 못하였다(Table 4).

\section{혈중 근 손상 지표 물질의 변화}

혈중 creatine kinase $(\mathrm{CK})$ 는 안정 시 가장 낮은 수치를 보이다 운동 후 24 시간 까지 지속적으로 증가하는 경향을 보 였으며, taping 처치 후 농도는 낮게 나타났다. CK의 변화 양 상과는 반대로 lactate dehydrogenase $(\mathrm{LDH})$ 의 농도 변화는 운동 직후 가장 높은 농도를 보이다 회복이 진행됨에 따라 점차 낮아져 회복 24 시간 시기에서 안정 시 만큼 회복되었다. $\mathrm{CK}$ 와 $\mathrm{LDH}$ 농도에 대한 taping 전후 및 채혈시기 간의 차이를 알아보기 위해 ANOVA를 실시한 결과, 시기에 따른 차이는 유의하였으나 $(\mathrm{p}<0.001)$ 처치 전후에 의한 차이는 통계적으로 유의하지 못하였다. Taping 전후에 있어 $\mathrm{CK}$ 의 평균 농도는 처치 전후에 $15.46 \mathrm{IU} / 1$ 의 차이를 보였으며, $\mathrm{LDH}$ 의 경우에는 더 적은 $5.18 \mathrm{IU} / 1$ 의 차이를 보이며 사후 더 낮은 수치를 보였 다. 이를 통하여 taping 처치가 혈중 근 손상 지표물질의 농도

Table 4. Comparison of fatigue factors

\begin{tabular}{|c|c|c|c|}
\hline & Resting & End of exercise & Recovery \\
\hline \multicolumn{4}{|c|}{ Ammonia (ng/ml) } \\
\hline NK & $30.82 \pm 2.59$ & $154.87 \pm 14.70$ & $32.54 \pm 3.36$ \\
\hline K & $29.72 \pm 4.09$ & $140.57 \pm 31.26$ & $32.07 \pm 3.91$ \\
\hline \multicolumn{4}{|c|}{ Phosphorous (mg/dl) } \\
\hline NK & $3.72 \pm 0.28$ & $4.91 \pm 0.49$ & $3.59 \pm 0.31$ \\
\hline $\mathrm{K}$ & $3.66 \pm 0.34$ & $4.61 \pm 0.56$ & $3.61 \pm 0.38$ \\
\hline
\end{tabular}

Values are mean \pm standard deviation.

K: with kinesio taping, NK: without kinesio taping. 
Table 5. Comparison of muscle damage index

\begin{tabular}{cccccc}
\hline \multicolumn{7}{c}{ Resting } & End of exercise & Recovery $30 \mathrm{~min}$ & Recovery $4 \mathrm{hr}$ & Recovery $24 \mathrm{hr}$ \\
\hline NK & $212.60 \pm 49.03$ & $273.50 \pm 50.20$ & $297.10 \pm 48.49$ & $319.32 \pm 61.35$ & $315.20 \pm 47.83$ \\
K & $206.60 \pm 65.81$ & $264.20 \pm 39.64$ & $273.50 \pm 51.34$ & $299.54 \pm 58.22$ & $296.60 \pm 71.43$ \\
\hline NK & $305.00 \pm 33.37$ & $345.20 \pm 35.62$ & $334.90 \pm 42.20$ & $319.90 \pm 39.07$ & $303.90 \pm 38.08$ \\
K & $304.70 \pm 40.57$ & $330.00 \pm 36.26$ & $325.30 \pm 42.09$ & $321.10 \pm 39.48$ & $301.90 \pm 42.00$ \\
\hline
\end{tabular}

Values are mean \pm standard deviation.

$\mathrm{K}$ : with kinesio taping, NK: without kinesio taping.

Table 6. Comparison of Creatinine and IGF-I

\begin{tabular}{cccc}
\hline & Resting & End of exercise & Recovery \\
\hline \multicolumn{4}{c}{ Creatinine $(\mathrm{mg} / \mathrm{dl})$} \\
\hline NK & $1.06 \pm 0.08$ & $1.19 \pm 0.10$ & $1.07 \pm 0.08$ \\
K & $1.06 \pm 0.08$ & $1.18 \pm 0.08$ & $1.08 \pm 0.15$ \\
\hline \multicolumn{4}{c}{ IGF-I $(\mathrm{ng} / \mathrm{dl})$} \\
\hline NK & $418.30 \pm 43.21$ & $488.70 \pm 37.56$ & $416.30 \pm 59.71$ \\
K & $413.40 \pm 49.06$ & $474.90 \pm 41.87$ & $419.50 \pm 52.88$ \\
\hline
\end{tabular}

Values are mean \pm standard deviation.

K: with kinesio taping, NK: without kinesio taping.

개선에는 유의한 영향을 나타내지 못함을 발견할 수 있었다 (Table 5).

\section{Creatinine 및 IGF-|의 변화}

혈중 Creatinine과 IGF-I 농도의 변화 양상은 유사하였으며 운동 종료 후 가장 높은 수치를 보였으며 creatinine은 회복 24 시간, IGF-I은 회복 30 분에 안정 시 만큼 회복되었다. 혈중 creatinine의 평균 농도는 taping 전후에 따른 차이가 나타나지 않았으며 IGF-I의 경우에도 $5.17 \mathrm{ng} / \mathrm{dl}$ 의 작은 차이를 보이며 taping 후 감소하였으나 통계분석 결과 유의한 차이는 나타나 지 않았다(Table 6).

\section{고 찰}

Taping은 관절의 보강 및 보호, 부종 감소, 또는 급성 손상 시 관리를 위해 고정을 목적으로 적용해 왔으며[22]. 이후, 근 골격계의 손상시 피부 및 근육에 직접 테이프를 부착하여 통 증의 감소를 꾀할 뿐 아니라[20] 근력, 근지구력 등의 기능 향 상을 목적으로도 테이핑 방법들이 개발되어 다양하게 적용되 고 있다[10,21,35].

Kinesio taping은 관절을 움직이는 근육의 결을 따라 붙여 줌으로써 근육과 피부사이의 혈액과 림프순환을 증가시켜 근 육의 운동기능을 향상시킬 뿐만 아니라 치료의 목적으로도 사용되고 있다. Braakman 등[2]은 테이핑을 적용한 골절환자
들에서 재골절의 위험이 감소됨을 보였는데, 그 원인을 근력 의 향상으로 설명하였으며, Hunter [19]는 스포츠 손상 후 테 이핑 적용으로 재손상의 방지뿐만 아니라 관절가동범위와 근 력의 회복에 효과가 있었음을 보고하였다. 또한 Shelton[38]은 PFD (patellofemoral dysfunction) 환자들에게 테이핑을 사용 한 결과, 대퇴사두근의 근력증강 효과를 입증하였다

본 연구에서도 kinesio taping 적용 후, 1-RM 및 등속성 운 동능력의 증가가 발견되었다. 우선 1-RM의 경우 Bench Press 와 Leg Press에서 kinesio taping 적용 후 각각 $7 \mathrm{~kg}$ 과 22.60 $\mathrm{kg}$ 의 증가를 보였다. 등속성 운동능력에서는 kinesio taping 적용 후, 슬관절의 경우 extension과 flexion 시 각각 25.20 $\mathrm{Nm} / \mathrm{kg}(\%)$ 와 $10.80 \mathrm{Nm} / \mathrm{kg}$ (\%)가 증가하였으며, 견관절에서 도 extension과 flextion 시 각각 $6.20 \mathrm{Nm} / \mathrm{kg}$ (\%)와 3.50 $\mathrm{Nm} / \mathrm{kg}(\%)$ 의 증가를 보였다. 이와 같은 증가를 나타낸 것은 테이핑을 부착했을 때 그 부착 피부 아래 골격근내 감마-운동 신경이 흥분하여 섬유자체의 장력을 증가[26]시킨 것 같으며, 테이핑 부착부위에 동시적으로 많은 수의 시냅스전 신경섬유 의 흥분이 도달하게 됨으로써 신경의 여러 장소에서 흥분성 전달물질이 유리되는 공간적 가중현상으로 상가 작용이 나타 나 근의 장력이 증가되어 근력이 향상된 것이라 생각된다. 그 리고, 테이핑을 통해 근육에 대한 자극의 강도가 증가되어 근 수축력의 증가를 유발시켰으며, 상호신경지배 작용[3]을 통해 테이핑이 부착부에 자극을 주어 굴곡근의 수축성은 더욱 활성 화되고 신전근은 억제되어 이완됨으로써 근력이 향상된 것이 라 할 수 있다.

피로는 장기간의 운동이나 계속되는 자극에 의해서 한 기관 이나 그 기관 일부의 반응 또는 기능이 감소된 상태[28]라 할 수 있다. 피로로 인해 근육의 장력이 감소되는데, 이는 근육내 수소이온, ammonia, phosphorous 등 여러 가지 대사 물질의 축적과 관련이 있다. 이들 피로물질의 농도는 운동 종료 시 최고를 보이고 이후 지속적으로 감소하는데 대부분의 운동에 서는 이들 피로물질의 농도가 회복 1 시간 이내에 안정 시 만큼 회복된다 $[6,25,28]$ 고 보고 이러한 이유로 운동 1 시간 이후의 근 통증(Delayed Onset Muscle Damage)은 근 피로로 설명할 수 없다는 견해도 있다[39,42]. 이는 taping 적용 전후 모두에 
서 운동 직후의 피로물질(ammonia, phosphorus) 농도는 안정 시와 회복 30 분에 비하여 유의하게 높았으며 안정시와 회복 30 분 간의 농도차이는 거의 나타나지 않은 본 연구의 결과와 도 일치한다.

본 연구에서 ammonia 및 phosphorous의 평균 농도는 taping 적용 전보다 후에 더 낮은 수치를 보였으나, 통계적으로 유의한 차는 보이지 않았다. 본 연구에서 근손상 유발 수단으 로 사용된 웨이트트레이닝의 강도( $85 \%-1 \mathrm{RM})$ 와 지속시간으로 볼 때 암모니아 축적은 ATP 이용율이 ATP 재합성량을 초과 하여 발생한 것으로 보이며[43], taping 적용에 따른 암모니아 와 무기인산 농도상의 유의한 차이가 나타나지 않은 것은 $\mathrm{CPr}$ 가수분해의 증감 또는 무기인산을 이용한 ATP 생성 시스템의 활성정도, 그리고 에너지 생성에 있어 해당과정(glycolysis)의 비율 등에서 차이가 나타나지 않았다는 것을 의미하는 것이 다. 본 연구에서의 $1 \mathrm{RM}$ test와 등속성 운동능력 결과를 고려해 볼 때 근력의 증가는 Type I fiber의 농원비율을 증가시키고 이것은 Type II fiber의 동원비율 감소로 이어져 PNC cycle에 의한 phosphorus 농도 감소와 해당과정을 통한 에너지 공급 율의 감소를 가져올 수 있음을 의미한다. 또한 ammonia의 생 성 역시 PNC의 활성과 밀접한 관련이 있으므로 결국 근력의 향상은 동일한 운동 강도에서 운동 시 혈중 피로물질의 감소 로 이어져야 한다. 하지만 본 연구의 결과에서 나타난 ammonia와 phosphorus 농도변화는 taping 후 감소의 경향만 보였 을 뿐 통계적 유의성은 나타나지 않았다. 이는 $85 \% 1-R M$ 강도 의 웨이트트레이닝은 고강도의 운동이며 운동에 소요된 시간 도 40 분 정도로 장시간이지만 다양한 근육부위에 적은 반복수 와 set를 적용하였기 때문에 피로물질의 축적이 현저하지 않 은 것으로 생각된다.

혈중 $\mathrm{CK}$ 와 $\mathrm{LDH}$ 의 활성은 주로 격렬한 운동으로 인한 근 조직손상의 지표로 사용되어왔다[37]. 근육 손상과 지연된 근 통증(Delayed Onset of Muscle Soreness: DOMS)에 대한 정확 한 기전은 아직 밝혀지지 않았지만, 운동 후 근육 손상의 지표 인 혈중 $\mathrm{CK}$ 와 $\mathrm{LDH}$ 농도의 지속적인 증가 현상은 아마도 근육 손상에 따른 급성적인 염증 반응 후 식세포의 증가된 활동에 의한 것으로 볼 수 있고[7], cross-bridge의 근 손상에 따른 구 조적 변형에 의한 반응 현상으로 간주되고 있다[8].

본 연구에서의 taping 전후에 있어 $\mathrm{CK}$ 의 평균 농도는 처치 전후에 $15.46 \mathrm{IU} / 1$ 의 차이를 보였지만, 통계적으로 유의하지 못하였다. 일반적으로 $\mathrm{CK}$ 의 활성은 근섬유의 동원 비율에 있 어서 Type I 섬유의 동원비율보다는 Type II 섬유의 동원비율 이 높은 운동에서 피로유발과 근육 자체의 손상이 더욱 크게 나타난다[23]. 즉 CK 농도는 Type II 섬유의 동원량에 비례한 다고도 할 수 있는데, 본 연구에서 taping에 따른 CK 농도 차이가 나타나지 않은 결과는 taping 전후에 근섬유의 동원형 태의 차이가 경미하였음을 의미하는 것으로 볼 수 있다.

$\mathrm{LDH}$ 는 $\mathrm{CK}$ 와 마찬가지로 근질환이나 구조적 손상을 가장
잘 반영한다고 알려져 있다. 본 연구에서 $\mathrm{LDH}$ 는 유의한 차는 나타나지 않았지만 taping 처치 전후 $5.18 \mathrm{IU} / 1$ 의 차이를 보이 며 사후 더 낮은 수치를 보였다. 웨이트 운동 후 근육경련이 발생하면 통증이 유발되어 국소 부위로 가는 혈액의 양이 줄 어들게 된다. 이로 인해 피로 물질 등이 쌓이게 되어 대사 장애 를 일으키게 되는데, 이렇게 순환에 문제가 생긴 부위에 kinesio taping을 적용하면 테이프가 갖고 있는 탄력성으로 인해 피부와 천근막을 들어 올리게 되어 그 사이에 공간이 생기게 된다. 이 공간으로 근육이 수축함에 따라 밖으로 나온 삼출액 이 림프관 안으로 들어가기 쉽게 됨으로써 변화된 조직압력이 정상화되고, 또한 혈류나 림프액의 흐름이 원활하게 되어 통 증을 경감시켜 $\mathrm{LDH}$ 의 감소를 가져온 것으로 생각된다.

Creatinine은 골격근의 creatine phosphate 농도와 관련이 있다. 이를 근거로, creatinine은 골격근에서 이화작용의 부산 물과 같은 creatine으로부터 생성된다고 보고 근력 향상을 측 정하는 하나의 수단으로 사용되었다[12,13,17].

본 연구에서도 kinesio taping에 의한 creatine 이화작용의 정도를 관찰하기 위하여 혈중 creatinine 농도를 분석한 결과 taping 전후에 따른 평균농도의 차이는 나타나지 않았다. 이는 taping에 의한 근력 증가가 ATP-CP system의 활성 정도의 유의한 차이를 유도하지 못하였으며 운동으로 creatine 이화 작용에 의해 생성된 creatinine은 운동 후 24시간에 이르러서 는 urine으로 배출되었음을 보여주는 결과라 할 수 있다. 또한 creatinine은 골격근의 creatine phosphate의 양을 반영하므로 taping이 creatine phosphate의 농도 증가를 가져오지 못하였 기 때문에 creatinine 농도가 변화하지 않은 것으로도 볼 수 있다.

Creatinine과 마찬가지로 상대적인 운동 강도를 대변해 주 는 도구로 사용할 수 있는 것이 혈중 IGF-I 농도이다. 근육에 주어지는 자극은 피로와 근 손상을 유발시키기도 하지만 근 비대에 필수적인 IGF-I의 활성 역시 증가시키기 때문에 여러 선행연구 $[5,36]$ 에서는 자극의 상대적인 크기 또는 근비대에 대 한 효과를 알아보기 위하여 혈중 IGF-I 농도를 이용하여 왔다.

이에 본 연구에서도 kinesio taping이 웨이트트레이닝의 상 대적인 자극의 크기에 어떠한 영향을 미치는지를 관찰하기 위하여 IGF-I 농도를 관찰한 결과 통계적으로 유의한 차는 나 타나지 않았지만, taping 적용 운동 후 $5.17 \mathrm{ng} / \mathrm{dl}$ 의 감소를 보였다. 근비대의 진행과정에는 local satellite cell의 활성이 필수적인데, Mauro[24]에 의해 최초로 제안된 이 세포는 myofibers의 sarcolemma와 세포외부 영역 사이에서 분열한다. 또한, 이 세포외부영역에서 발견된 것은 Insulin-like Growth Factor-I (IGF-I) 과 같은 면역 단백체의 유사분열이며, 외부에 서의 특정한 자극이 주어지면 IGF-I이 satellite cell 가까이에 서 세포를 유사분열 시킨다[36]. 이는 외부에서 주어지는 자극 의 정도에 의해 혈중 발현도가 결정된다는 것을 의미하며, 이 를 근거로 할 때 kinesio taping이 웨이트트레이닝에 대한 상 
대적인 강도에 영향을 미치지 못하였음을 알 수 있다.

이상의 결과로 kinesio taping은 근력의 직접적인 지표 향상 에는 긍정적인 영향을 미치지만 혈중성분들을 유의하게 변화 시키지는 못함을 알 수 있었다. 이는 훈련에 의한 근육의 양적 증가 또는 기능성보조제 투여 등으로 인한 에너지 기질의 농 도 변화와 같은 내적인 변화가 아닌 신체 외부로부터의 한시 적인 자극에 의한 근력향상이므로 그 차이가 크게 나타나지 않은 것으로 보인다.

하지만 이미 특정 대근육에 대한 반복적인 운동에 kinesio taping을 적용하여 피로 및 근 손상 완화를 입증한 연구들도 있으며 본 연구에서 나타난 혈중 성분들의 긍정적인 변화 양 상으로 미루어 kinesio taping의 피로 및 근 손상 완화 효과를 부정할 수는 없는 것으로 생각한다.

\section{References}

1. Balint, G. and B. Szebenyi. 1998. Non-pharmacological therapies in osteoarthritis. Baillière's Clinical Rheunatology 11, 795-815.

2. Braakman, M., E. Oderwal, and M. H. Haentjens. 1998. Functional taping of fractures of the 5th metacarpal results in a quicker recovery. Injury 29, 5-9.

3. Burke, J. R. and G. Kamen. 1996. Changes in spinal reflexes preceding a voluntary movement in young and old adults. Biological Sciences \& Medical Sciences 51, M17-22.

4. Cushnaghan, J., C. McCarthy, and P. Dieppe. 1994. Taping the patella medially: a new treatment for osteoarthritis of the knee joint? British Medical Journal 308, 753-755.

5. Deschenes, M. R. and W. J. Kraemer. 2002. Performance and physiologic adaptations to resistance training. American Journal of Physical Medicine and Rehabilitation 81, S3-16.

6. Donnelly, A. E., P. M. Clarkson, and R. J. Maughan 1992. Exercise-induced muscle damage: effects of light exercise on damaged muscle. European Journal of Applied Physiology 64, 350-353.

7. Faulkner, J. A., S. V. Brooks, and J. A. Opiteck. 1993. Injury to skeletal muscle fibers during contractions: conditions of occurrence and prevention. Physical Therapy 73, 911-921.

8. Friden, J., J. Seger, and B. Ekblom. 1988. Sublethal muscle fibre injuries after high-tension anaerobic exercise. European Journal of Applied Physiology and occupational physiology 57, 360-368.

9. Garrack, J. G. 1977. The frequency of injury mechanism of injury and epidemiology ankle sprain. American Journal of Sports Medicine 5, 231-242.

10. Gilleard, W., J. McConnell, and D. Parsons. 1998. The effect of patellar taping on the onset of vastus medialis obliquus and vastus lateralis muscle activity in persons with patellofemoral pain. Physical Therapy 78, 25-32.

11. Go, D. I. 1999. Taping \& Muscle Relaxation Stimulation Therapy. Korean Journal of Family Medicine 20, 1637-1642.

12. Greenhaff, P. L., K. Bodin, K. Soderlund, and E. Hultman. 1994. Effect of oral creatine supplementation on skeletal muscle phosphocreatine resynthesis. American Journal of Physiology 266, E725-730.

13. Ha, C. S. 2002. The effects of low doses of creatine and creatine loading on strength, urinary creatinine concentration, and body composition. The Korean Journal of Physical Education 41, 813-824.

14. Halseth, T., J. W. McChesney, M. DeBeliso, R. Vaughn, and J. Lien. 2004. The effects of kinesio taping on proprioception of the ankle. Journal of Sports Science and Medicine 3, 1-7.

15. Hinman, R. S., K. M. Crossley, J. McConnell, and K. L. Bennell. 2003. Efficacy of knee tape in the management of osteoarthritis of the knee: blinded randomised controlled trial. British Medical Journal 327, 135-142.

16. Host, H. H. 1995. Scapular taping in the treatment of anterior shoulder impingement. Physical Therapy 75, 803-812.

17. Hultman, E., K. Söderlund, J. A. Timmons, G. Cederblad, and P. L. Greenhaff. 1996. Muscle creative loading in men. Journal of Applied Physiology 81, 232-237.

18. Hunter, D. and D. Felson. 2004. Therapeutic knee taping improved pain and disability in osteoarthritis of the knee. ACP Journal Club 140, 7-14.

19. Hunter, L. Y. 1985. Braces and taping. Clinics Sports Medicine 4, 439-454.

20. Kowall, M. G., G. Kolk, G. W. Nuber, J. E. Cassisi, and S. H. Stern. 1996. Patellar taping in the treatment of patellofemoral pain. A prospective randomized study. The American Journal of Sports Medicine 24, 61-66.

21. Larsen, B., E. Andreasen, A. Urfer, M. R. Mickelson, and K. E. Newhouse. 1995. Patellar taping: a radiographic examination of the medial glide technique. The American Journal of Sports Medicine 23, 465-471.

22. Leanderson, J., S. Ekstam, and C. Salomonsson. 1996. Taping of the ankle-the effect on postural sway during perturbation, before and after a training session. Knee Surgery, Sports Traumatology, Arthroscopy 4, 53-56.

23. Linnamo, V., R. Bottas, and P. V. Komi. 2000. Force and EMG power spectrum during and after eccentric and concentric fatigue. Journal of Electromyography and Kinesiology 10, 293-300.

24. Mauro, A. 1961. Satellite cell of skeletal muscle fibers. The Journal of Biophysical and Biochemical Cytology 9, 493-495.

25. Miller, P. C., S. P. Bailey, M. E. Barnes, S. J. Derr, and E. E. Hall. 2004. The effects of protease supplementation on skeletal muscle function and DOMS following downhill running. Journal of Sports Science 22, 365-372.

26. Murphy, P. R. and G. R. Hammond. 1997. Reversal of fusimotoreflex responses during locomotion in the decerebrate cat. Experrimenal Physiology 82, 837-858.

27. Murray, H. and L. Husk. 2001. Effect of kinesio taping on proprioception in the ankle. Journal of Orthopedic Sports Physical Therapy 31, A-37.

28. Mutch, B. J. and E. W. Banister. 1983 Ammonia metabolism in exercise and fatigue. Medicine and Science in Sports and Exercise 15, 41-50.

29. Ng, G. Y. and J. M. Cheng. 2002. The effects of patellar taping on pain and neuromuscular performance in subjects 
with patellofemoral pain syndrome. Clinical Rehabilitation 16, 821-827.

30. No, J. K. 1998. The study of the revelation ability of muscles for the increasing flying distance of golfers through the application of the kinesio taping method.. Ph. D. Thesis, Kyonggi University, Suwon, Kyonggi.

31. Park, Y. S. and H. J. Kim. 2005. Effects of a taping method on pain and ROM of the knee joint in the elderly. Journal of Korean Academy of Nursing 35, 372-381.

32. Perrin, D. H. 2005. Athletic taping and bracing. pp. 5-15, 2nd eds., Human Kinetics. Champaign, IL.

33. Pfeiffer, R. P., M. DeBeliso, K. G. Shea, L. Kelley, B, Irmischer, and C. Harris. 2004. Kinematic MRI assessment of McConnell taping before and after exercise. American Journal of Sports Medicine 32, 621-628.

34. Ramón, T., M. Prades, L. Armengou, J. L. Lanovaz, D. R. Mullineaux, and H. M. Clayton. 2004. Effects of athletic taping of the fetlock on distal limb mechanics. Equine Veterinary Journal 36, 764-768.

35. Retting, A. C., K. S. Stube, and K. D. Shelboume. 1997. Effects of finger and wrist taping on grip strength. The American Journal of Sports Medicine. 25, 96-98.

36. Sara, V. R. and K. Hall. 1990. Insulin-like growth factors and their binding proteins. Physiological Reviews 70, 591-614.

37. Schwane, J. A., S. R. Johnson, C. B. Vandenakker, and R.
B. Armstrong. 1983. Delayed-onset muscular soreness and plasma CPK and LDH activities after downhill running. Medicine and Science in Sports Exercise 15, 51-56.

38. Shelton, G. L. 1992. Conservative management of patellofemoral dysfunction. Primary Care 19, 331-350.

39. Vickers, A. J., P. Fisher, C. Smith, S. E. Wyllie, and G. T. Lewith. 1997. Homoeopathy for delayed onset muscle soreness: a randomised double blind placebo controlled trial. British Journal of Sports Medicine 31, 304-307.

40. Wee, S. D. and Y. H. Seo. 2003. Effect of kinesio taping on isokinetic function and fatigue of thigh muscle. The Korean Journal of Physical Education 42, 405-417.

41. Yoon, N. M. and Y. S. Seo. 2001. The Effects of Kinesio taping on Lumbar muscle strength and Flexibility. The Journal of Korean Society of Physical Therapy 13, 579-584.

42. Yu, J. G., L. Carlsson, and L. E. Thornell. 2004. Evidence for myofibril remodeling as opposed to myofibril damage in human muscles with DOMS: an ultrastructural and immunoelectron microscopic study. Histochemistry and Cell Biology 121, 219-227.

43. Zhao, S., R. J. Snow, C. G. Stathis, M. A. Febbraio, and M. F. Carey. 2000. Muscle adenine nucleotide metabolism during and in recovery from maximal exercise in humans. Journal of Applied Physiology 88, 1513-1519.

\title{
초록 : Kinesio taping이 근력, 혈중 피로물질 및 근 손상 물질 농도변화에 미치는 영향
}

\author{
이민선 · 백일영 ${ }^{1} \cdot$ 곽이섭 $^{2} \cdot$ 노희태 $^{1} \cdot$ 진화은 ${ }^{1 *}$ \\ (선문대학교 물리치료학과, ${ }^{1}$ 연세대학교 체육교육학과, ${ }^{2}$ 동의대학교 체육학과)
}

본 연구의 목적은 kinesio taping 적용이 근력 향상에 미치는 영향을 직 - 간접적으로 관찰함으로써 운동 수행 시의 상해예방 및 수행력 향상을 위한 수단으로서의 taping 요법에 대한 기초 자료를 제공하는데 있었다. 본 연구 는 남자 대학생 10 명을 대상으로, 근력 향상의 정도를 직접적으로 관찰하기 위하여 1RM test와 Cybex test를 실 시하였으며, 생리학적 변인으로는 CK, LDH, phosphorus, ammonia, creatinine, IGF-I의 6가지 혈중 성분을 분석 함으로써 피로와 근 손상의 정도를 분석하였다. 본 연구를 통하여 kinesio taping은 근력향상의 직접적인 지표 $(1 \mathrm{RM}$, 등속성 운동능력)에는 긍정적으로 작용했지만, $85 \%-1 \mathrm{RM}$ 의 웨이트트레이닝 시의 근 피로 또는 근 손상 지표물질의 농도는 유의하게 감소시키지 못함을 알 수 있었다. 하지만 본 연구의 결과만을 가지고 taping의 적용 이 피로 및 근 손상 완화 효과가 없다고 판단할 수는 없을 것으로 생각된다. 왜냐하면, 본 연구에서의 피로 및 근 손상 유발 수단인 85\%-1RM 웨이트트레이닝은 고강도의 운동이며 운동에 소요된 시간도 40 분 정도로 장시간 이지만 다양한 근육부위에 적은 반복수와 set를 적용하였기 때문에 피로 및 근 손상 지표물질의 축적이 현저하지 않았을 수 있기 때문이다. 이는 taping 적용 후 나타난 여러 혈중성분들의 감소(Creatinine 제외) 경향으로 설명할 수 있으며, 실제로 선행 연구 중 특정 대근육에 대한 반복적인 운동에 kinesio taping을 적용하여 피로 및 근 손상 완화를 입증하기도 하였다. 본 연구가 가지는 의의는 특정 동작에 있어서의 근력 향상을 중점적으로 관찰한 연구 가 아닌, 전신에 대한 taping을 적용한 후 각 근육 부위에 어떠한 영향을 미치는지 다양한 관점에서 관찰하였다는 데 있다. 이후의 연구에서는 본 연구에서 관찰한 변인들 이외에도 신경계통의 변인들과의 상관관계도 함께 관찰 하는 통합적인 연구도 의의가 있다고 하겠다. 